\title{
DATA MEASUREMENTS AND ITS USES FOR THE AUTONOMOUS SYSTEM
}

\author{
František Ostř́ǐžek ${ }^{1}$, Oldřich Trenz ${ }^{1}$ \\ ${ }^{1}$ Department of Informatics, Faculty of Business and Economics, Mendel University in Brno, Zemědělská 1, 61300 \\ Brno, Czech Republic
}

To cite this article: OSTŘǏŽEK FRANTIŠEK, TRENZ OLDŘICH. 2018. Data Measurements and its Uses for the Autonomous System. Acta Universitatis Agriculturae et Silviculturae Mendelianae Brunensis, 66(6): 1581-1587.

To link to this article: https://doi.org/10.11118/actaun201866061581

\begin{abstract}
This article describes the problematic area of UAV (Unmanned Aerial Vehicle). This device can be used to communicate with corporate IS and other devices, calculation of localisation, mapping of new places which covered with Wi-Fi technology and many others purposes. Nowadays, trends in the solution of driving and maintenance describe precise localisation. The fundamental error of GPS while using it inside buildings is enormous, and for this reason, we were trying to use infrastructure based on $802.11 \mathrm{a} / \mathrm{b} / \mathrm{g} / \mathrm{n}$. It takes a focus on the part of measuring of signals and the ability of Wi-Fi signals processing. A limiting factor for this solution might be an environment with a weak or null signal and situations with a smaller amount of beacons. The primary aim of this article is providing an introduction to the problem of use drones and describe collected data for future use.
\end{abstract}

Keywords: drone, Wi-Fi, localization, connectivity

\section{INTRODUCTION}

When we use UAV (Unmanned Aerial Vehicle) as an extended eye for a dangerous area, then we need some support system to make decisions. The operator of a tele-operated device has many problems with changing an environment. It is a problem especially when we talk about movement inside of buildings (Yayla, 2017). For this purpose, a device must be tele-operated by more than one person or the device must be controlled by a collection of algorithms for semi-autonomous function which need to be implemented.

The use of autonomous concepts, in this case, is the only choice. Especially, when we think of an in-house application like a final type of building, warehouse or hazardous area (MA, 2017; Sato, 2017). There may be constraints for interaction between a human operator and an environment (Schenker, 1990). From this point of view, the automatisation can reduce the cost of final implementation. Using this concept in bussiness environment is mostly provided by specialised applications (Hegeir, 2017). Firstly, it is essential to solve situations when the device is on a collision trajectory. In this case a fast solution for safety distance or stable state is needed (Wild, 2016).

The law prohibits the use of a autonomous drone in an open space with a focus on general safety and the privacy of individuals. The Czech Republic has a legislative framework described by CR 49/1997. It is evident that the law rules have constraints, because they were published in the year 1997. It does not reflect on the growing field of research and usage of such devices in the future. Many companies are experimenting with autonomous functions in logistics (Amazon Prime Air). With a focus on the potential application of human life, we can think of changing the law for the use of new technologies and approaches to a statute for the privacy of people or groups of people (Royal Mail 
may use drones, 2015; using drones, 2015, Civilian Use of Drones (EUC Report), 2015, Walmart wants the Amazon-like delivery drones, 2015, Unmanned aerial vehicles in logistics, 2014 (Certification at the CAA - Flight and Aviation License, 2014; the sky, 2015; Pašková, 2015; Petř́ková, 2016). Except for the law change, we can wait for constraints of public operation (The Czech Law 49/1997, sb.).

The application of flying drone can be partly tele-operated and we can accept some free implemented function for a critical situation or fully automated service. The human factor is necessary because of responsibility. We can choose application by place of deployment (mapping and record of an environment, recognize of object, use to the max height of surroundings building, etc.). In all cases, we can expect the use of well-known constraints of an environment which can be described by the model (map of the environment, description of an object, an effect of space), then we can tag implementation of an abstract layer as a simplification. A solution can consist of fully automated tasks of the drone in 3D space, requirements for movement and the ability of adaptation for a new situation taken by a camera sensor or different type of device sensor (Statt, 2018).

When we work with drone in-house, we have to keep in mind the constraints of local environment. For example, position of walls, windows, doors etc. In case of an environment where interaction with employees is expected, we must create rules for the behaviour and safety tools which help to raise the security. Take a limit for free objects, people, animals etc. (Lawson, 2018).

Nowadays, we can meet this technology in construction, where it is comparing progress with plan and mapping aspects of safety in the workplace (Irrizary, 2012). Usage of drone devices in public space is discussed and analysed for general confidence of this technology. We can describe several accidents when drones were recording sports competitions and public shows.

It is critical when the hobby device is controlled near the no-flight zones, which are defined around airports, army areas, nuclear power plants, etc. (Forrest, 2015). In an exceptional situation, it is a problem of users, which can be constrained by the legislative framework.

As mentioned above, pre-defined environment strongly decreases computation performance, therefore deploying fully automated device (drone) can be helpful. Many people have ideas how to implement a corporate application for a public area. The ideas have constraints in the law and technology. On the other side, deploying fully autonomous solution has many unsolved issues in the field of behaviour and responsibility. Who is responsible for an accident? Company or software engineer? (Drones: Autonomous or automated?, 2017; law ČR 49/1997, sb.)

Before building a device, many issues should be considered, such as battery pack, sensors, cameras, propellers, engines, materials of frame, design of the device and others. (Flynt, 2017; Winkler, 2016; Unmannedtech, 2015)

The count of sensors has impact on used algorithms (map of environment, optimisation of flight trajectory etc.). The necessary criterium is: who will process the data? The device or remote computer? When we choose the latter, then we can think about a connection to an information system. There is a possibility to provide information for group of drones coordination (Ozirkovskyy, 2016).

From above mentioned requirements, many types of competitions simulating problems of nowadays arise and with them their rules (Clifford, 2017; Hambling, 2018).

The solved problems also includes the area of computer vision with methods and algorithms for image processing (Lysek et al., 2012; Minarik et al., 2008; Skorpil et al., 2009).

\section{MATERIALS AND METHODS}

For business, it is essential to find factors that determine the successful localisation inside of buildings and define movements in them. Many authors focus on determination of these factors for example Yang (2017), Hayajneh (2016), Kotaru (2018), Serrano et al. (2014), Liu et al. (2014) Da Costa Botelho et al. (2009) and many others. It is possible to distinguish three primary aspects of localisation without using GPS:

1) beacons, markups, landmarks, specific environment

2) computer vision

3) measurement of physical values

4) combination of previous methods

Each of these approaches allows usage of remote computation power and assimilation of autonomous functions into the corporate information system. For this configuration, it is necessary to create a connector and determine character of transmitted data between device modules and IS (Information System).

Wang's (2010) article describes advanced localisation and identification in warehouse unit through RFID technology (Radio Frequency Identification). When we complement computer vision with data read from crate ticket and use SLAM algorithms (Simultaneous Localisation and Mapping), then we can create low-cost checker of supplies and security employee in one device.

An idea how to do it in-house is by using WI-FI technology. As described in Fig. 1. every corporate object has its own wireless network. In this case, we need to identify overlaps (Fig. 1, Ch 44). Well-designed infrastructure has high availability and we can use triangulation method over it as a whole. An ideal example is a wireless signal as a sphere with transmitter as the centre. There two types of transmitters. One has transmitting power at constant level, the other type changes the power level on distance basis. 
Many specialised software like Ekahau can validate this idea and we can get results like in Fig. 2. from raw data gathered via network wireless card. In Linux-like systems, we can write "\$iwlist [network interface] scan". The output of this program is complete information about available Wi-Fi. For custom localisation, we need at least three beacons, but more is better.
As shown in Fig. 2, we can have blind space. In this case and when offline, we must trust other methods like vision odometry and distance measurement.

In Fig. 3 a) we can see the model of the described situation. We have the position of the transmitter and altitude of the device. From this example, we calculate right corner triangle. The problem is that

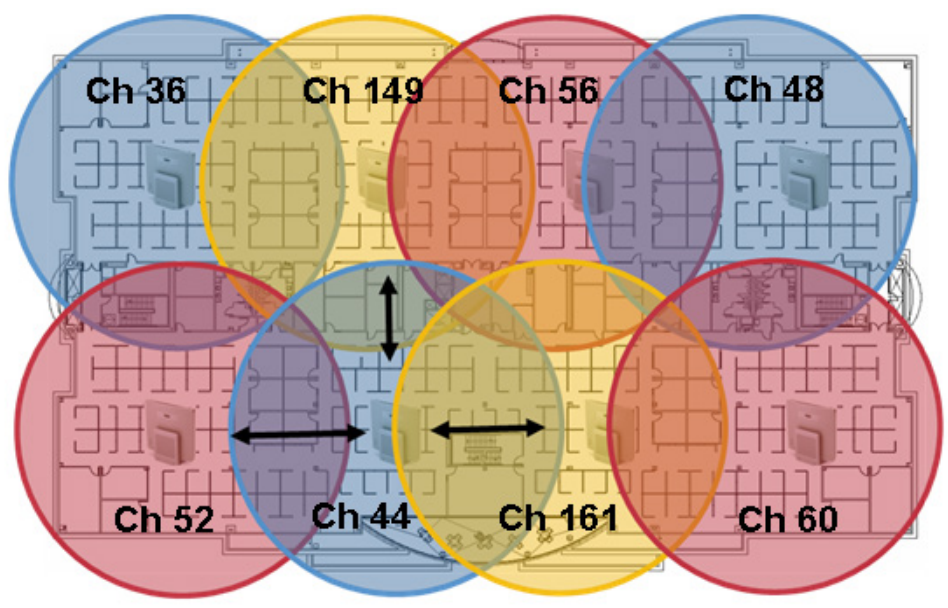

1: Design of overlaps in building

Source: https://www.cisco.com/c/dam/en/us/support/docs/wireless/5500-series-wireless-controllers/ 116057-site-survey-guidelines-wlan-10.png

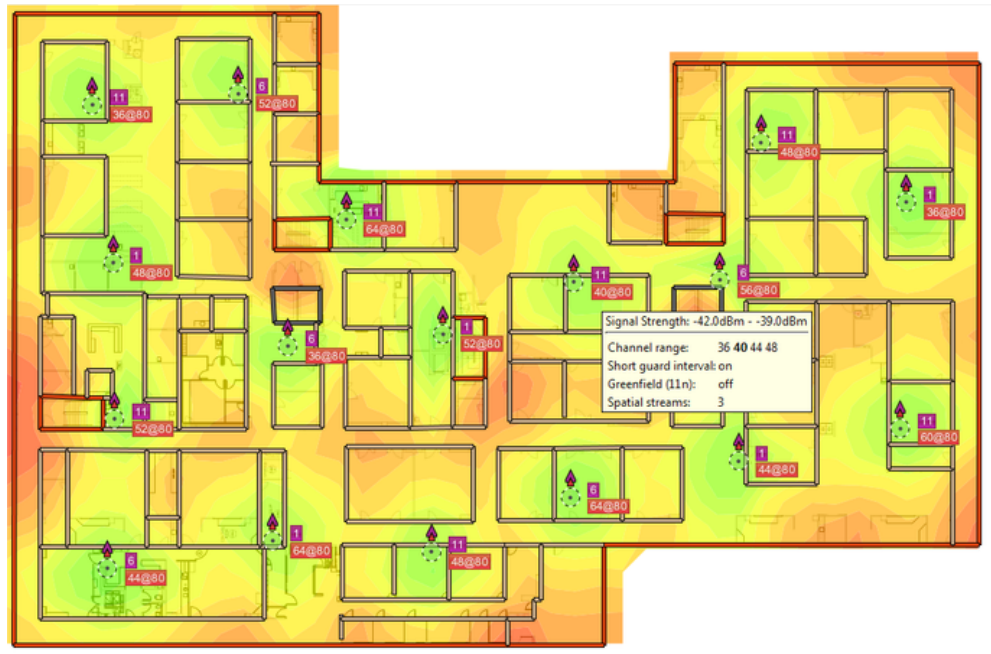

2: Output from program Ekahau

Source: https://www.file-extensions.org/imgs/app-picture/4964/ekahau-site-survey.png
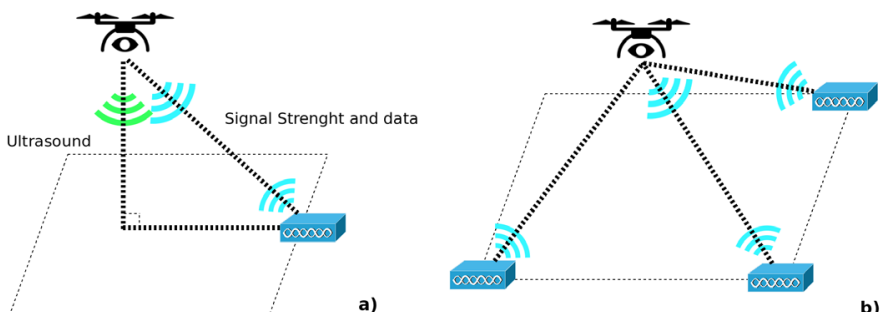

3: Explained idea for communication and localisation 


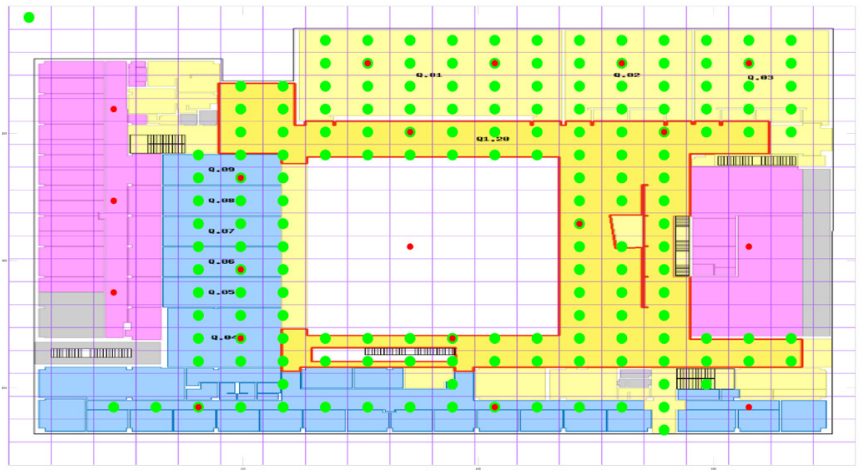

4: Dataset for building Q, Mendel university in Brno (first floor)

Signal level for tile $[7,1]$

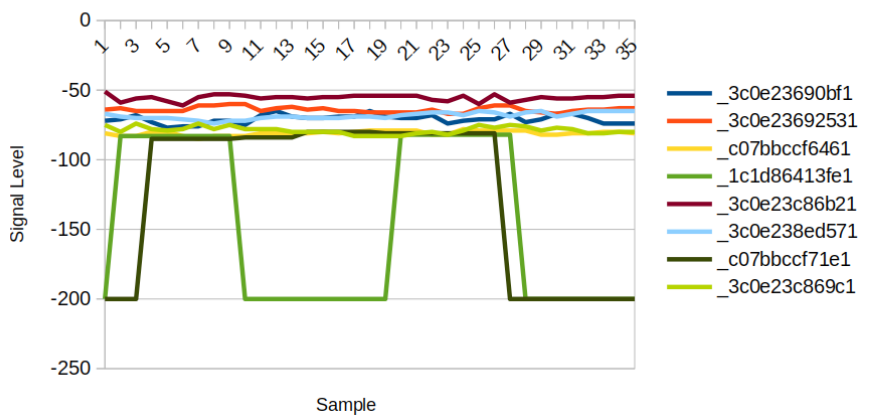

5: Signal Level of AP's in cell [7,1]

Deviation of signal Level in cell $[7,1]$

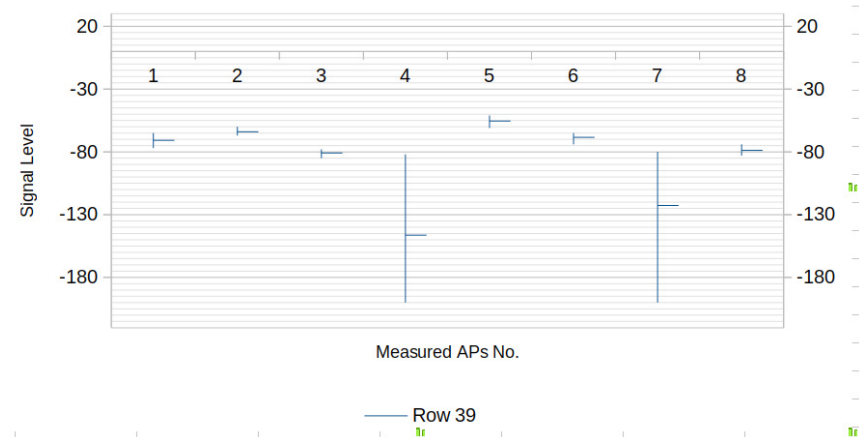

6: Signal deviation in cell $[7,1]$

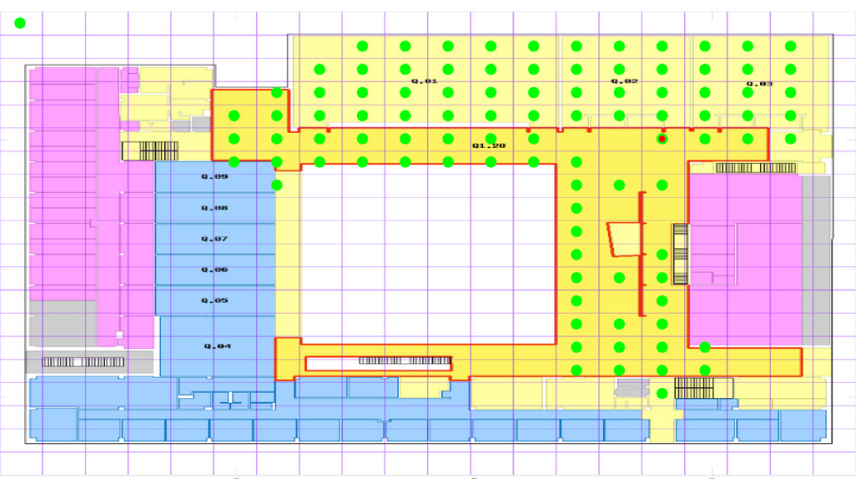

7: Data for single AP on first floor of building $Q$ 
the result is only one-dimensional value (point of a circle). For this reason, it is necessary to have three transmitters. From three transmitters we can calculate two points (Fig. 3 b). One of them we can dismiss, because of probabilistic math used with continuous trajectory.

The dataset is taken from Master's degree thesis Approximation of a mobile device position using known network of Wi-Fi access-points.

\section{RESULTS}

The blind map in Fig. 4 was taken from university webserver and is overlayed with data from the thesis mentioned above (green dots). The red dots indicate position of transmitters. Rectangles in the map (squares in the real map resolution) are 3 by 3 meters areas.

In other ways, the device can be coordinated by the central server and do its job faster together with other devices. It is essential to keep in mind the idea of methods fusing data from sensors like camera, distance measurement and localisation module.
As shown in Fig. 5, there are 35 samples measured for every cell (rectangle 3 by 3 ) of the dataset. The graph indicates that the power level is mostly linear and the assumption, that the transmitters are of the type with dynamic transmitting power, can be made.

In a case when we have a weak area of Wi-Fi signal, then we can rely on an algorithm of computer vision or localise from another source, or return to last known position and recalculate path by graph algorithm.

The Fig. 6 shows signal deviation for a single cell. The following signal processing usage procedure can be deduced it and also the creation of bit-word for each area. Thusly defined areas can then be filtered by classification algorithms.

Fig. 7 shows area coverage by single AP which is placed in building Q. It is obvious that there are significant overlaps and they will help codify bit-words for higher logic of localisation. The measured data display high deviation in marginal areas. This way we can filter out misleading data from the transmitter.

\section{DISCUSSION AND CONCLUSIONS}

Same as Wang (2010) describes his localisation by RFID technology, we can create the same function for different types of technology like Wi-Fi and Bluetooth. Experiments show that Bluetooth approach (Estimote Inc.) needs to connect to a beacon. It is wrong idea because you lose approximately three seconds for searching, reconnecting and localisation. On the other hand, Wi-Fi technology transmits a signal continuously and the data can be read from the operating system. Noised environment creates a need to implement a filter and method for comparative data reading. This only works for transmitters with variable power level.

Without filtering and machine learning approach we can create a crude algorithm based on the bitmap of Wi-Fi signals. That can be great for an approximate position like as "north-east" part of a building (expected raw data from Fig. 5). This method is weak for precise localisation and classifies the methods without data post-processing into the group of support algorithm. That can be interesting when we check the presence of a person in a place like as an office, laboratory, classroom and others places.

We use Parrot ARdrone like many authors (Santana, 2016; Arokiasami, 2016; etc.) and Raspberry Pi extension. It is connected to the router and is processing low-level logic. Other authors send the data over a network to the central server and calculate all data on the server. When they lose the Wi-Fi signal, they can then expect undefined behaviour. The solution has hypothetic network setup requirements for radius authentication on the controller like eduroam. In this case, we don't lose network connection and continue on the job. This only works for transmitters with constant power level.

The Wi-Fi localisation has an advantage because we can use many different kinds of devices like smartphones or notebooks for another job.

\section{Acknowledgements}

The results presented in this paper are supported by project MENDELU IGA DP_0042017 and Department of Informatics of FBE Mendelu.

\section{REFERENCES}

AMAZON. 2015. Amazon Prime Air. Amazon. [Online]. Available at: https://www.amazon.com/AmazonPrime-Air/b?node=8037720011 [Accessed: 2018, February 21].

AROKIASAMI, W. A., VADAKKEPAT, P., TAN, K. C. and SRINIVASAN, D. Interoperable multi-agent framework for unmanned aerial/ground vehicles: towards robot autonomy. Complex $\varangle$ Intelligent Systems, 2(1): 45-59.

BÄHNEMANN, R., PANTIC, M., POPVIĆ, M. et al. 2017. THE ETH-MAV Team in the MBZ International Robotics Challenge. Journal of Field Robotics, 2018: 0-0. 
CLIFFORD, C. 2017. NASA raced a Google-funded robot drone against a world-class human pilot-here's what happened. CNBC Make It. [Online]. Available at: https://www.cnbc.com/2017/11/22/google-fundednasa-drone-competition-ai-drone-versus-human-pilot.html [Accessed: 2018, February 21].

DA COSTA BOTELHO, S. S., DREWS, P., OLIVEIRA, G. L. and DA SILVA FIGUEIREDO, M. 2009. Visual odometry and mapping for Underwater Autonomous Vehicles. In: 2009 6th Latin American Robotics Symposium (LARS 2009). 29-30 Oct. 2009, Valparaiso, Chile. IEEE.

DHL. 2014. Unmanned aerial vehicles in logistics. Troisdorf: DHL Customer Solutions $\odot$ Innovation. Available at: http://www.dhl.com/content/ dam/downloads/g0/about us/logistics insights/dhl trend report uav.pdf [Accessed: 2018, February 21].

ESTIMOTE. 2018. Inc. indoor location with bluetooth beacons and mesh. Estimote. [Online]. Available at: https://estimote.com [Accessed: 2018, February 21].

FLYNT, J. 2017. Choosing the Right Sized Drone. 3dinsider.com [Online]. Available at: http://3dinsider.com/ drone-sizes/ [Accessed: 2018, February 21].

FORREST, C. 2015. 12 drone disasters that show why the FAA hates drones. Techrepublic.com [Online]. Available at: https://www.techrepublic.com/article/12-drone-disasters-that-show-why-the-faa-hatesdrones/ [Accessed: 2018, February 21].

HAMBLING, D. 2018. At This Drone Competition, To Win Is To Destroy. Popularmechanics.com [Online]. Available at: https://www.popularmechanics.com/flight/drones/al6810528/droneclash-dronecompetition/ [Accessed: 2018, February 21].

HAYAJNEH, A. M., ZAIDI, S. A. R., MCLERNON, D. C. and GHOGHO, M. 2016. Optimal Dimensioning and Performance Analysis of Drone-Based Wireless Communications. In: 2016 IEEE Globecom Workshops (GC Wkshps). IEEE, pp. 1-6.

HEGEIR, O., NAGAI, K., MATSUMOTO, K. and MIZUTANI, T. 2017. Inspection and Detection of Damages of Main Cable in Pathein Bridge Using Drone. In: Eighth International Conference on Science and Engineering (ICSE 2017). Yangon Technological University, Myanmar, pp. 1027-1031.

IRRIZARY, J., GHEISARI, M. and WALKER, B. 2012. Usability Assessment of Drone Technology as Safety Inspection Tools. ITcon, 17: 194-212.

KOTARU, M., JOSHI, K., BHARADIA, D. and KATTI, S. 2015. SpotFi. ACM SIGCOMM Computer Communication Review, 45(5): 269-282.

LAWSON, S. 2018. 12 Tips for Safely and Successfully Flying Drones Indoors. Droneguru.net [Online]. Available at: http://www.droneguru.net/12-tips-for-safely-and-successfully-flying-drones-indoors/ [Accessed: 2018, February 21].

LIU, Y., DASHTI, M., ABD RAHMAN, M. A. and ZHANG, J. 2014. Indoor localization using smartphone inertial sensors. In: 2014 11th Workshop on Positioning, Navigation and Communication (WPNC). 12-13. March, Dreseden, Germany. IEEE, pp.

LYSEK, J., STASTNY, J. and MOTYCKA, A. 2012. Object recognition by means of evolved detector and classifier program. In: MENDEL 2012, 18th International Conference on Soft Computing. Brno: Mendel University, pp. 82-87.

MA, Y., SELBY, N. and ADIB, F. 2017. Drone Relays for Battery-Free Networks. In: SIGCOMM '17. August 21-25, 2017, Los Angeles, CA, USA. Los Angeles: SIGCOMM.

MEASURE. 2017. Drones: Autonomous or automated? Measure Blog. [Online]. Available at: http://www. measure.com/blog-2017/drones-autonomous-or-automated [Accessed: 2018, February 21].

MINARIK, M. and STASTNY, J. Recognition of Randomly Deformed Objects. In: MENDEL 2008, 14 $4^{\text {th }}$ International Conference on Soft Computing. Brno: Mendel University, pp. 275-280.

OZIRKOVSKYY, L., PASHCHUK, Y., MASHCHAK, A. and VOLOCHIY, S. 2016. The automation of the exploitation risks assessment of the navigationinformation system of air drones. In: $201613^{\text {th }}$ International Conference on Modern Problems of Radio Engineering, Telecommunications and Computer Science (TCSET). IEEE, pp. 140-144.

PARLIAMENT UK. 2015. Civilian use of drones (EUC Report). Available at: http://www.publications.parliament. uk/pa/ld201516/ldhansrd/ text/150908-0002.htm“\#15090852000142 [Accessed: 2018, February 21].

PAŠKOVÁ, M. 2015. Potenciál využití dronů v armádě České republiky. Státní ozbrojené a bezpečnostní složky. [Online]. Available at: http://www.ozbrojeneslozky.cz/ clanek/potencial-vyuziti-dronu-v-armade-ceskerepubliky [Accessed: 2018, February 21].

PETŘÍKOVÁ, H. 2016. K čemu je dron v pojištovně? Ekon Tech.cz. [Online]. Available at: http://www.ekontech. cz/clanek/cemu-je-dron-pojistovne-usnadnuje-praci-setri-cas-naklady [Accessed: 2018, February 21 ].

SANTANA, L. V., BRANDÃO, A. S. and SARCINELLI-FILHO, M. 2016. Navigation and Cooperative Control Using the AR.Drone Quadrotor. Journal of Intelligent $\odot$ Robotic Systems, 84(1-4): 327-350.

SATO, Y., OZAWA, S., TERASAKA, Y. et al. 2017. Remote radiation imaging system using a compact gamma-ray imager mounted on a multicopter drone. Journal of Nuclear Science and Technology, 55(1): 90-96.

SCHENKER, P. S. and BEJCZY, A. K. 1990. Workspace visualization and time-delay telerobotic operations. In: Guidance and control 1990; Proceedings of the Annual Rocky Mountain Guidance and Control Conference. Keystone, CO, Feb. 3-7, 1990 (A91-26801 10-12). San Diego, CA: Univelt, Inc., pp. 613-624. 
SERRANO, O., PLAZA, J. M. C., MATELLÁN, V. and RODERO-MERINO, L. 2004. Robot localization using WiFi signal without intensity map. In: V Workshop de agentes Físicos. Marzo 2004, Gerona, España, pp. 79-88. SHELL. 2018. Eye in the sky. Shell. [Online]. Available at: http://www.shell.com/inside-energy/eye-in-thesky.html [Accessed: 2018, February 21].

SKORPIL, V. and STASTNY, J. Comparison Methods for Object Recognition. In: Proceedings of the 13th International Conference on Systems. Rhodos, Greece, 2009, pp. 607-610.

STATT, N. 2018. Skydio's AI-powered autonomous Rl drone follows you around in 4K: This drone can be flown without expertise and doesn't even come with a controller. The verge. [Online]. Available at: https://www.theverge.com/2018/2/13/17006010/skydio-rl-autonomous-drone-4k-video-recording-aicomputer-vision-mapping [Accessed: 2018, February 21].

SZENTRPÉTERIL, K., SETIAWAN, T. and ISMANTO, A. 2016. Drones (UAV's) in mining and exploration. An application example: Pit Mapping and Geological Modelling. In: Unconventional Exploration Target $\sigma^{\circ}$ Latest Technique and New Tools in Mineral and Coal Exploration. Bandung, West Java, Indonesia, 5-6 October 2016, MGEI $8^{\text {th }}$ Annual Convention.

TAYLOR, R. 2015. Royal mail may use drones. Mail Online. Available at: www.dailymail.co.uk/news/ article-3311214/Drones-one-day-deliver - post-rural-addresses-head-Royal-Mail-suggested-yesterday. html [Accessed: 2018, February 21].

TECHWORLD. 2017. 15 uk companies using drones. 2015. Techworld. [Online]. Available at: http://www. techworld.com/picture-gallery/personal-tech/6-best -uses-of-drones-in-business-3605145/ [Accessed: 2018, February 21].

UNMANNEDTECH, A. 2015. LiPo Batteries - How to choose the best battery for your drone. Dronetrest.com [Online]. Available at: https://www.dronetrest.com/t/lipo-batteries-how-to-choose-the-best-battery-foryour-drone/1277 [Accessed: 2018, February 21].

USA TODAY. 2015. Walmart wants amazon-like delivery drones. Usatoday. Available at: http://www.usatoday. com/story/money/2015/10/26/ walmart-wants-to-use-drones-to-deliver-packages/74646996/ [Accessed: 2018, February 21].

WANG, C-S. 2010. Adaptive RFID positioning system using signal Level Matrix. International Journal of Computer, Electrical, Automation, Control and Information Engineering, 4(10): 1558-1564.

WILD, G., MURRAY, J. and BAXTER, G. 2016. Exploring Civil Drone Accidents and Incidents to Help Prevent Potential Air Disasters. Aerospace, 3(4): 22-33.

WINKLER, C. 2016. How Many Sensors are in a Drone, and What do they Do? Sensors Online. [Online]. Available at: https://www.sensorsmag.com/components/how-many-sensors-are-a-drone-and-what-dothey-do [Accessed: 2018, February 21].

YANG, H., LEE, Y., JEON, S-Y and LEE, D. Multi-rotor drone tutorial: systems, mechanics, control and state estimation. Intelligent Service Robotics, 10(2): 79-93

YAYLA, A. and SPECKHARD, A. 2017. The Potential Threats Posed by ISIS's Use of Weaponized Air Drones and How to Fight Back. ICSVE Brief Reports. 